\title{
MIF wt Allele
}

National Cancer Institute

\section{Source}

National Cancer Institute. MIF wt Allele. NCI Thesaurus. Code C50954.

Human MIF wild-type allele is located in the vicinity of $22 \mathrm{q} 11.23$ and is less than $1 \mathrm{~kb}$ in length. This allele, which encodes macrophage migration inhibitory factor (MIF)

(phenylpyruvate tautomerase) protein, is involved in cell-mediated immunity, immunoregulation, and inflammation. 